\title{
Correction to: Effect of phosphate on sorption of Eu(III) by montmorillonite
}

\author{
Madhuri A. Patel ${ }^{1} \cdot$ Aishwarya S. Kar ${ }^{1} \cdot$ Sumit Kumar $^{1}$ - B. S. Tomar ${ }^{1}$
}

Published online: 22 May 2018

(C) Akadémiai Kiadó, Budapest, Hungary 2018

\section{Correction to: \\ J Radioanal Nucl Chem (2017) 313:537-545 https://doi.org/10.1007/s10967-017-5304-0}

On page 538, in second column/line number 5 , the value for the cation exchange capacity of the Na-montmorillonite clay is $23 \mathrm{meq}$ per $100 \mathrm{~g}$ instead of $87 \mathrm{meq}$ per $100 \mathrm{~g}$.

The original article can be found online at https:// doi.org/10.1007/s10967-017-5304-0.

\section{Aishwarya S. Kar} aishj@barc.gov.in

1 Radioanalytical Chemistry Division, Bhabha Atomic Research Centre, Mumbai 400085, India 